\title{
Anterior Insular Cortex is Critical for the Propensity to Relapse Following Punishment-Imposed Abstinence of Alcohol Seeking
}

\author{
(DErin J. Campbell, ${ }^{1,2}$ Jeremy P.M. Flanagan, ${ }^{1,2}$ Leigh C. Walker, ${ }^{1,2}$ Mitchell K.R.I. Hill, ${ }^{1,2}$ Nathan J. Marchant, ${ }^{1,2,3}$ \\ and Andrew J. Lawrence ${ }^{1,2}$ \\ ${ }^{1}$ The Florey Institute of Neuroscience and Mental Health, Parkville, Victoria 3052, Australia, ${ }^{2}$ Florey Department of Neuroscience and Mental Health, The \\ University of Melbourne, Victoria 3010, Australia, and ${ }^{3}$ Department of Anatomy and Neurosciences, VU University Medical Center, Amsterdam, 1081 HZ, \\ The Netherlands
}

Humans with alcohol use disorder typically abstain because of the negative consequences associated with excessive drinking, and exposure to contexts previously associated with alcohol use can trigger relapse. We used a rat model that captures a characteristic of this human condition: namely voluntary abstinence from alcohol use because of contingent punishment. There is substantial variability in the propensity to relapse following extended periods of abstinence, and this is a critical feature preventing the successful treatment of alcohol use disorder. Here we examined relapse following acute or prolonged abstinence. In male alcohol preferring P rats, we found an increased propensity to relapse in Context $\mathrm{B}$, the punishment context after prolonged abstinence. Next, we found that neither alcohol intake history nor the motivational strength of alcohol predicted the propensity to relapse. We next examined the putative circuitry of context-induced relapse to alcohol seeking following prolonged abstinence using Fos as a marker of neuronal activation. The anterior insular cortex (AI) was the only brain region examined where Fos expression correlated with alcohol seeking behavior in Context $B$ after prolonged abstinence. Finally, we used local infusion of $\mathrm{GABA}_{\mathrm{A}}$ and $\mathrm{GABA}_{\mathrm{B}}$ receptor agonists (muscimol + baclofen) to show a causal role of the AI in context-induced relapse in Context $\mathrm{B}$, the punishment context after prolonged abstinence. Our results show that there is substantial individual variability in the propensity to relapse in the punishmentassociated context after prolonged abstinence, and this is mediated by activity in the AI.

Key words: alcohol use disorder; anterior insular cortex; context; iP rat; punishment; relapse

Significance Statement

A key feature of alcohol use disorder is that sufferers show an enduring propensity to relapse throughout their lifetime. Relapse typically occurs despite the knowledge of adverse consequences including health complications or relationship breakdowns. Here we use a recently developed rodent model that recapitulates this behavior. After an extended period of abstinence, relapse propensity is markedly increased in the "adverse consequence" environment, akin to humans with alcohol use disorder relapsing in the face of adversity. From a circuitry perspective, we demonstrate a causal role of the anterior insular cortex in relapse to alcohol seeking after extended abstinence following punishment imposed voluntary cessation of alcohol use.

\section{Introduction}

Individual variation in the expression of particular traits contributes to the onset of neuropsychiatric disease states, including drug addiction (Piazza et al., 1989). Variation in the propensity to

\footnotetext{
Received June 25, 2018; revised 0ct. 15, 2018; accepted Nov. 4, 2018.

Author contributions: E.J.C. wrote the first draft of the paper; E.J.C., L.C.W., N.J.M., and A.J.L. edited the paper; E.J.C., N.J.M., and A.J.L. designed research; E.J.C., J.P.M.F., L.C.W., and M.K.R.I.H. performed research; E.J.C. analyzed data; E.J.C. and A.J.L. wrote the paper.

This work was supported by a National Health and Medical Research Council Project Grant (1105741); A.J.L. is a NHMRC Principal Fellow (1116930) and E.J.C. is supported by the University of Melbourne Early Career Researcher Grant Scheme; and we acknowledge the Victorian State Government Operational Infrastructure Scheme. We thank Lauren McKeogh, Pascale Maynard, Shubham Ranjan, Shubo Jin, and Liubov Lee-Kardashyan for their help with behavioral and Fos experiments and Christina Perry for thoughtful discussions.

The authors declare no competing financial interests.
}

relapse following extended abstinence is a critical feature preventing successful treatment of addiction (Gossop et al., 1989). In abstinent alcoholics, environments previously associated with alcohol use provoke relapse (Wikler, 1973; O’Brien, 1997). In rodents, this is modeled using ABA renewal (Bouton and Bolles, 1979) where self-administration of alcohol occurs in one context (Context A) followed by extinction (experimenter-imposed) of alcohol-reinforced responding in a difference context (Context $B)$. Renewal is observed when the rodent is returned to the orig-

Correspondence should be addressed to Andrew J. Lawrence at andrew.lawrence@florey.edu.au or Erin J. Campbell at erin.campbell@florey.edu.au.

https://doi.org/10.1523/JNEUROSCI.1596-18.2018

Copyright $\odot 2019$ the authors $\quad 0270-6474 / 19 / 391077-11 \$ 15.00 / 0$ 
inal alcohol-associated context (Context A; Crombag and Shaham, 2002; Hamlin et al., 2007). However, abstinence in humans is often voluntary because of the adverse consequences of alcohol use (Klingemann, 1991; Blume et al., 2006) without any treatment intervention.

We modified a variation of the ABA renewal model where abstinence is self-imposed in Context $B$ because of adverse consequences (punishment; Marchant et al., 2013) by examining alcohol seeking following extended abstinence ( $30 \mathrm{~d}$ ). First, we determined the propensity to relapse to context-induced alcohol seeking following prolonged abstinence after punishment-imposed suppression of alcohol use. We found an increased propensity to relapse in Context B, the punishment context after prolonged abstinence. Second, we determined the predictability of this propensity to relapse using alcohol intake history and the motivational strength of alcohol. Neither factor predicted relapse. Third, we examined the putative circuitry of context-induced relapse to alcohol seeking following prolonged abstinence using Fos expression (Dragunow et al., 1987). The anterior insular cortex (AI) was the only brain region examined where Fos expression correlated with alcohol seeking in the punishment context after prolonged abstinence. Finally, we demonstrated a causal role of the AI in context-induced relapse using local infusion of muscimol and baclofen to reversibly inactivate the AI which essentially prevented relapse in Context B, the punishment context after prolonged abstinence, but not acute abstinence.

\section{Materials and Methods \\ Ethics statement}

All procedures performed were in accordance with the Prevention of Cruelty to Animals Act (2004), under the guidelines of the National Health and Medical Research Council (NHMRC) Australian Code of Practice for the Care and Use of Animals for Experimental Purposes (2013) and approved by The Florey Institute of Neuroscience and Mental Health Animal Ethics Committee.

\section{Animals}

Inbred male iP rats ( $\sim 8$ weeks old, total $n=129)$ were obtained from the breeding colony at the Florey. Parental stock was previously obtained from T. K. Li (while at Indiana University). All rats were pair-housed except during Experiments 4 and 5 where they were single-housed. Food (Barastoc rat and mouse, Ridley) and water were available ad libitum and all rats were maintained on a normal $12 \mathrm{~h}$ light/dark cycle (07:00 lights on).

\section{Apparatus}

Standard operant chambers (Med Associates) enclosed in a ventilated sound-attenuating cubicle were used for self-administration. Each chamber was equipped with two retractable levers and grid floors were connected to shockers. An active lever press resulted in the delivery of $20 \%$ ethanol $(0.1 \mathrm{ml} /$ delivery $)$ into the receptacle. An inactive lever press had no consequence. Contexts A and B were manipulated as in our previous study (Campbell et al., 2018): illumination level (white/no house light), background (stripes/none), bedding (saw dust/recycled paper), background noise (fan off/on).

\section{Experiment 1: effect of context-induced relapse to alcohol seeking following acute or prolonged abstinence}

The behavioral procedure (Fig. $1 \mathrm{~A}$ ) was the same as previously published (Campbell et al., 2018).

\section{Behavioral procedure (4 phases)}

Phase 1: home-cage alcohol intake. An intermittent access (3-4 times/ week) alcohol procedure (Wise, 1973; Simms et al., 2008) was used where rats received $8 \times 24 \mathrm{~h}$ sessions of access to $20 \% \mathrm{v} / \mathrm{v}$ alcohol. In Experiments 4 and 5, rats received $12 \times 24$ h home-cage sessions. Alcohol solutions were prepared in tap water from $100 \%(\mathrm{v} / \mathrm{v})$ ethanol. Daily sessions began at 09:00. After $24 \mathrm{~h}$, the alcohol was replaced with a second water bottle for the subsequent $24-48 \mathrm{~h}$ alcohol-free period. The follow- ing day, the second water bottle was replaced with $20 \%$ alcohol, and the location of the alcohol was alternated from the previous session. Total alcohol consumption was calculated for each session, using the weight difference between the beginning and end of the session, minus $1 \mathrm{~g}$ for spillage, multiplied by 0.97 (density of $20 \%$ ethanol), and divided by 2 (number of rats per cage).

Phase 2: operant self-administration: Context A. All rats were given one $16 \mathrm{~h}$ overnight training session where only the active lever was presented. An active lever press resulted in the delivery of $0.1 \mathrm{ml}$ of $20 \%$ alcohol into a receptacle followed by a $2 \mathrm{~s}$ light cue above the active lever. Food and water was provided ad libitum. Rats were then trained for seven $20 \mathrm{~min}$ self-administration sessions under a fixed-ratio 1 (FR-1) schedule. Responding on the active lever resulted in the delivery of $0.1 \mathrm{ml}$ of $20 \%$ alcohol and the $2 \mathrm{~s}$ light cue followed by a $20 \mathrm{~s}$ timeout period where lever presses were recorded but not reinforced. Inactive lever presses were recorded but had no consequence. Following FR-1 training, rats progressed to a variable-interval $30 \mathrm{~s}$ (VI-30) schedule for six 20 min sessions where alcohol delivery was available after an active lever press at pseudorandom intervals (1-59 s) after the preceding alcohol delivery.

Phase 3: punishment: Context B. During $20 \mathrm{~min}$ sessions, rats selfadministered alcohol in an alternate context (Context B) under the same VI-30 schedule. Active lever presses resulted in the delivery of $0.1 \mathrm{ml}$ of alcohol paired with the $2 \mathrm{~s}$ light cue. 50\% of the reinforced active lever presses randomly resulted in a $0.5 \mathrm{~s}$ footshock $(0.2-0.7 \mathrm{~mA})$. Punished active lever presses resulted in footshock, $2 \mathrm{~s}$ light cue, and alcohol delivery. Inactive lever presses had no consequence. All rats were punished in Context $B$ for up to $6 \mathrm{~d}$, and footshock intensity was increased by $0.2 \mathrm{~mA}$ per session up to $0.6 \mathrm{~mA}$, or to $0.7 \mathrm{~mA}$ if rats made $>25$ active lever presses after three punishment sessions.

Phase 4: context-induced relapse test following either acute or prolonged abstinence. Rats in the acute abstinence protocol were tested for alcohol seeking the day after punishment-imposed abstinence (i.e., Day 1 Context $\mathrm{A}$ alcohol group, $n=12$; Day 1 Context $\mathrm{B}$ punishment group, $n=$ 12). Rats in the prolonged abstinence protocol were moved to a separate holding room for $29 \mathrm{~d}$ and tested for alcohol seeking on Day 30 (i.e., Day 30 Context A alcohol group, $n=23$; Day 30 Context B punishment group, $n=21$ ). All rats were tested under extinction conditions during 20 min sessions in either Context A or B in a counterbalanced order. During test, an active lever press under a VI-30 schedule resulted in delivery of the 2 s light cue but no alcohol or footshock.

\section{Experiment 2: predicting the propensity to relapse in the punishment context following prolonged abstinence}

On the third last day of Context A training, 14 rats were tested on a progressive ratio (PR) 3- 4 schedule for a single $2 \mathrm{~h}$ session. For the PR3-4 schedule, 32 active lever presses were required for the 10th infusion of alcohol (Farid et al., 2012), breakpoint was defined as the final ratio completed within the $2 \mathrm{~h}$ session. Subsequently, all rats received two further Context A sessions. Alcohol-reinforced responding was then punished in Context B. All rats were placed in a separate room for the prolonged abstinence phase. On abstinence Day 30, all rats were tested for alcohol seeking behavior in Context B.

\section{Experiment 3: effect of context-induced alcohol seeking following prolonged abstinence on Fos-protein expression}

Ninety minutes following the initiation of the relapse test, a subset of rats from Experiment 1 (i.e., Day 30 Context $\mathrm{A}$ alcohol group, $n=6$; Day 30 Context B punishment low relapsing group, $n=7$; Day 30 Context $\mathrm{B}$ punishment high relapsing group, $n=8$ ) were anesthetized (sodium pentobarbitone100 mg/kg, i.p.; Virbac). Rats were transcardially perfused with $\sim 100 \mathrm{ml}$ of $0.1 \mathrm{M}$ PBS followed by $\sim 400 \mathrm{ml}$ of $4 \%$ paraformaldehyde (PFA). Brains were removed and postfixed in PFA $(2 \mathrm{~h})$, then transferred to $30 \%$ sucrose in PBS $\left(48 \mathrm{~h}\right.$ at $\left.4^{\circ} \mathrm{C}\right)$. Brains were frozen over dry ice and stored at $-80^{\circ} \mathrm{C}$. Serial $(40 \mu \mathrm{m})$ coronal sections were cut using a Leica Microsystems cryostat and stored in $0.1 \mathrm{~m}$ PBS containing $0.1 \%$ sodium azide at $4^{\circ} \mathrm{C}$.

A 1-in-4 series of the whole brain was processed for Fosimmunoreactivity, as published (Campbell et al., 2015, 2017a). Free- 
A

\begin{tabular}{|c|c|c|c|c} 
Home-cage drinking & Self-administration training & Punishment & Abstinence period \\
\hline & Context A & Context B & Day 1 & Day 30 \\
& & $\begin{array}{c}\text { Relapse test in } \\
\text { A or B }\end{array}$ & $\begin{array}{c}\text { Relapse test in } \\
\text { A or B }\end{array}$
\end{tabular}

B

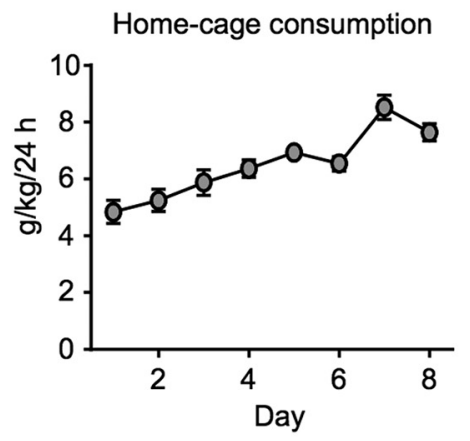

C

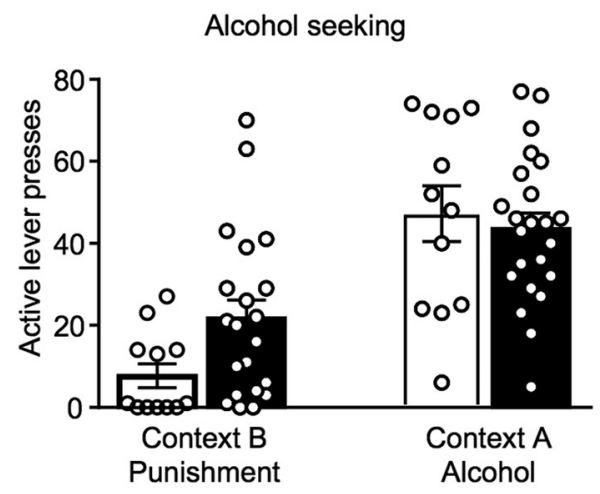

Training data

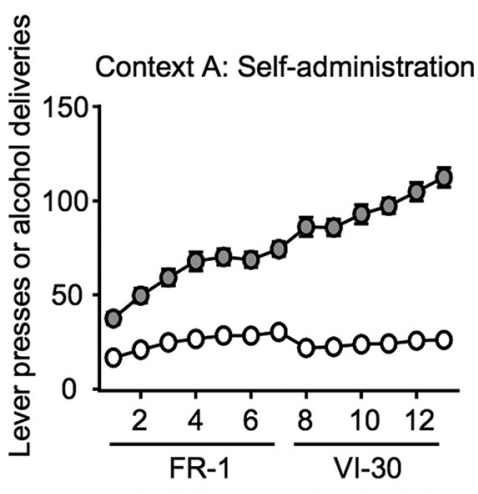

Reinforcement schedule

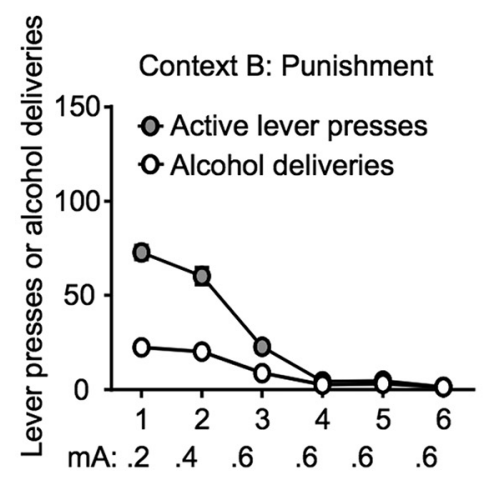

Alcohol seeking

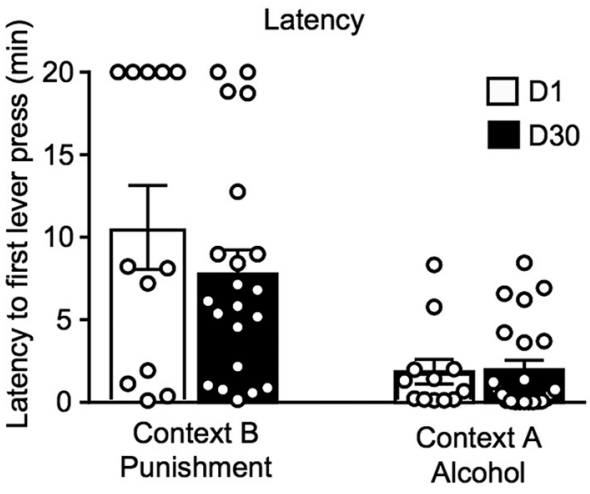

Figure 1. Home-cage intake, alcohol self-administration in Context $A$, and punishment of alcohol self-administration in Context $B$ and alcohol seeking behavior after acute and prolonged abstinence. Outline of the behavioral procedure ( $\boldsymbol{A})$. Alcohol intake (grams per kilogram) during the home-cage access phase. Context $A$ active lever presses and alcohol deliveries under the FR- 1 and VI-30 schedules of reinforcement. Context $B$ active lever presses and alcohol deliveries with the foot shock punishment range from 0.2 to $0.6 \mathrm{~mA}(\boldsymbol{B})$. Number of active lever presses (left) and latency to first lever press (right) during the relapse test at either Day 1 abstinence or Day 30 abstinence (C). Data are presented as mean \pm SEM. Total $n=68, n=12 /$ group Day 1 abstinence, $n=21$ Context B, punishment Day 30 abstinence group, $n=23$ Context A, alcohol Day 30 abstinence group. D1, Day 1 abstinence; D30, Day 30 abstinence.

floating sections were washed in PBS followed by blocking in 5\% normal horse serum (NHS). Sections were incubated $\left(48 \mathrm{~h}\right.$ at $\left.4^{\circ} \mathrm{C}\right)$ in $\mathrm{PBS}$ containing $0.5 \%$ Triton-X with $2 \%$ NHS and Fos primary antibody (1:3000; rabbit polyclonal, sc-52, Santa Cruz Biotechnology). Following primary incubation, sections were incubated $(2 \mathrm{~h})$ in biotinylated horse antirabbit secondary (1:300; BA-1100, Vector Laboratories). Subsequently, sections were incubated $(1 \mathrm{~h})$ in $\mathrm{ABC}$ reagent (Vector Laboratories) followed by incubation $(10 \mathrm{~min})$ in $0.1 \mathrm{M}$ sodium acetate with $0.025 \%$ diaminobenzidine in $2 \%$ nickel sulfate containing $2 \mathrm{mg} / \mathrm{ml} \mathrm{D-glucose}$, and $0.4 \mathrm{mg} / \mathrm{ml}$ ammonium chloride. Glucose oxidase $(0.2 \mu \mathrm{l} / \mathrm{ml})$ was added to visualize Fos. Sections were mounted onto gelatin-coated slides, air dried, and coverslipped.

Bright-field images of Fos-immunoreactive cells were captured using a MBF Biosciences Color 12-Bit (QImaging) camera attached to an upright Leica DMLB-2 microscope using a $10 \times$ objective. Images were quantified using iVision (BioVision) by an observer blinded to experimental conditions. Bilateral cell counts were quantified for each rat across 17 brain regions. These brain regions included the AI, posterior insular cortex (AIp), prelimbic cortex (PrL), infralimbic cortex (IL), lat- eral orbitofrontal cortex (LOFC), entorhinal cortex (EC), ventral subiculum (vSub), paraventricular thalamus (PVT), lateral hypothalamus (LH), lateral habenula ( $\mathrm{LHb})$, basolateral amygdala (BLA), central amygdala (CeA), medial amygdala (MeA) dorsal dentate gyrus (DDG), paraventricular nucleus of the hypothalamus, medial parvicellular part (PVN), nucleus accumbens core (NAcC), and nucleus accumbens shell (NAcSh). Please refer to Table 1 for more detail on bregma levels quantified. All brain coordinates were from Paxinos and Watson (2007).

Experiment 4: effect of AI inactivation on context-induced relapse to alcohol seeking in Context $B$, the punishment context, following prolonged abstinence

Surgery. Eighteen rats underwent behavioral training as per Experiment 1. During the abstinence period, rats were anesthetized with isoflurane (5\% induction, $2 \%$ maintenance) before being placed in a stereotaxic frame (Stoelting Instruments). Bilateral guide cannula (26-gauge; Plastics One) were positioned $1.5 \mathrm{~mm}$ above the $\mathrm{AI}$ (anteroposterior: +2.8 $\mathrm{mm}$, mediolateral: $\pm 4.4 \mathrm{~mm}$, and dorsoventral: $-4.7 \mathrm{~mm}$ from bregma; 
Table 1. Bregma levels and references for Fos quantification across several brain regions

\begin{tabular}{|c|c|c|}
\hline $\begin{array}{l}\text { Brain } \\
\text { region }\end{array}$ & Bregma level, mm & References \\
\hline $\mathrm{Al}$ & +3.08 to +2.76 & Arguello et al., 2017; Venniro et al., 2017; Nasser et al., 2018 \\
\hline Alp & -1.68 to -2.00 & Contreras et al., 2012 \\
\hline PrL & +3.72 to +2.76 & $\begin{array}{l}\text { Perry and McNally, 2013; Brown et al., 2016; } \\
\text { Burgos- Robles et al., } 2017\end{array}$ \\
\hline IL & +3.72 to +2.76 & Perry and McNally, 2013 \\
\hline LOFC & +3.72 to +2.76 & Perry and McNally, 2013 \\
\hline EC & -5.72 to -6.24 & Ge et al., 2017 \\
\hline vSub & -5.72 to -6.24 & Marchant et al., 2016 \\
\hline PVT & -1.68 to -3.12 & Marchant et al., 2014; Campbell et al., 2017b \\
\hline LH & -1.68 to -3.12 & Marchant et al., 2014; Campbell et al., 2017b \\
\hline $\mathrm{LHb}$ & -2.96 to -3.44 & Marchant et al., 2014; Zuo et al., 2017 \\
\hline BLA & -2.48 to -2.80 & Campbell et al., 2017a \\
\hline CeA & -2.48 to -2.80 & Campbell et al., 2017a \\
\hline MeA & -2.48 to -2.80 & Campbell et al., 2017a \\
\hline DDG & -3.24 to -3.62 & Ge et al., 2017 \\
\hline PVN & -1.52 to -1.84 & James et al., 2014 \\
\hline $\mathrm{NACC} / \mathrm{I}$ & +2.04 to +1.72 & Marchant et al., 2014; Campbell et al., 2017a \\
\hline
\end{tabular}

Bregma levels and references for Experiment 3, which examined the effect of context-induced alcohol seeking following prolonged abstinence on Fos-protein expression.

Venniro et al., 2017; Nasser et al., 2018). Cannulae were anchored to the skull with screws and dental cement. After surgery, rats were administered meloxicam (3 mg/kg, i.p.; Troy Laboratories) and Baytril $(3 \mathrm{mg} / \mathrm{kg}$, i.p.; Bayer Health Care) for $3 \mathrm{~d}$. All rats were given $7 \mathrm{~d}$ recovery from surgery before experimentation.

Intracranial infusions. Three days preceding the test, rats underwent three daily habituation injections. These occurred in the operant training room and involved the connection of $40 \mathrm{~cm}$ polyethylene connectors (Plastics One) to both cannulae and activation of an automated syringe pump (Harvard Apparatus) for 2 min. Following this, connectors were left in place for an additional $2 \mathrm{~min}$. Connectors were then removed and rats were left in their home cages for $10 \mathrm{~min}$ before being moved back to their holding room. After $30 \mathrm{~d}$ abstinence, rats were tested for alcohol seeking (under extinction conditions) in Context B. Muscimol + baclofen $[\mathrm{M}+\mathrm{B}$; Tocris Bioscience; $(50+50) \mathrm{ng} / 0.5 \mu \mathrm{l} / \mathrm{h}$ emisphere $]$ was dissolved in sterile saline. The injectors extended $1.5 \mathrm{~mm}$ below the guide cannula tips. $0.5 \mu \mathrm{l} /$ hemisphere of $\mathrm{M}+\mathrm{B}(n=8)$ or vehicle $(n=10,0.9 \%$ saline) was infused bilaterally into the AI over $2 \min (0.25 \mu \mathrm{l} / \mathrm{min})$ using a Harvard Apparatus syringe pump connected to two $1 \mu$ microsyringes (SGE Analytical Science) via polyethylene tubing. Injectors were left in place for a further $2 \mathrm{~min}$. Rats were tested in Context B 5-10 min after infusions. Following this, rats were anesthetized (pentobarbitone 100 $\mathrm{mg} / \mathrm{kg}$, i.p.; Virbac) and methylene blue ( $0.5 \mu \mathrm{l} /$ hemisphere) was infused into the AI. Brains were removed and frozen over super-cooled isopentane, then cut into $40 \mu \mathrm{m}$ coronal sections using a Leica Microsystems cryostat and counterstained with neutral red to verify cannula placements (see Fig. 4C). One rat was excluded due to misplaced cannula.

\section{Experiment 5: effect of AI inactivation on context-induced relapse to alcohol seeking following acute abstinence}

Surgery. Twenty-nine rats underwent behavior training as per Experiment 1. After 11 Context A self-administration sessions, rats received AI intracranial guide cannula surgery as described in Experiment 4. All rats were given at least $7 \mathrm{~d}$ to recover from surgery before experimentation. Following recovery, all rats were exposed to six additional Context A sessions followed by punishment in Context B as described in Experiment 1.

Intracranial infusions. All rats received two habituation injections in Context $\mathrm{A}$ and two habituation injections in Context $\mathrm{B}$ before the relapse test. This involved the connection of $40 \mathrm{~cm}$ polyethylene connectors (Plastics One) to both cannulae and activation of an automated syringe pump (Harvard Apparatus) for 2 min. Following this, connectors were left in place for an additional $2 \mathrm{~min}$. After $1 \mathrm{~d}$ abstinence, rats were tested for alcohol seeking (under extinction conditions) in either Context A or B. $\mathrm{M}+\mathrm{B}$ [Tocris Bioscience $(50+50) \mathrm{ng} / 0.5 \mu \mathrm{l} / \mathrm{hemispher}$ was dissolved in sterile saline. The injectors extended $1.5 \mathrm{~mm}$ below the guide cannula tips. $0.5 \mu \mathrm{l} /$ hemisphere of $\mathrm{M}+\mathrm{B}$ (Context A: $n=6$, Context B: $n=5$ ) or vehicle (Context A: $n=6$, Context B: $n=5 ; 0.9 \%$ saline) was infused bilaterally into the AI over $2 \mathrm{~min}(0.25 \mu \mathrm{l} / \mathrm{min})$ using a Harvard Apparatus syringe pump connected to two $1 \mu \mathrm{l}$ microsyringes (SGE Analytical Science) via polyethylene tubing. Injectors were left in place for a further $2 \mathrm{~min}$. Three rats were excluded due to misplaced cannula, three rats were excluded due to ill health following surgery and 1 rat was excluded due to a program operational error.

Locomotor testing. Twenty-four hours after the relapse test, a subset of rats from Experiment 5 received either $\mathrm{M}+\mathrm{B}(n=8)$ or vehicle $(n=8)$ infusions into the AI and locomotor activity was recorded for $1 \mathrm{~h}$ (Med Associates; $43.2 \times 43.2 \times 30.5 \mathrm{~cm})$. Distance traveled $(\mathrm{m})$ was recorded using photobeam detectors. Following this, rats were anesthetized (pentobarbitone $100 \mathrm{mg} / \mathrm{kg}$, i.p.; Virbac) and methylene blue $(0.5 \mu \mathrm{l} / \mathrm{hemi-}$ sphere) was infused into the AI. Brains were removed and frozen over super-cooled isopentane, then cut into $40 \mu \mathrm{m}$ coronal sections using a Leica Microsystems cryostat and counterstained with neutral red to verify cannula placements (see Fig. 5C).

\section{Statistical analysis}

Data were analyzed separately for the four behavioral phases: home-cage alcohol intake, Context A training, Context B punishment, and contextinduced relapse tests. For Experiment 1, training and punishment data were analyzed using repeated-measures ANOVA examining a main effect of session. For the relapse test, between-subjects factors were Context (Context A or Context B) and Abstinence Day (Days 1 or 30). The dependent variables were total number of active lever presses (inactive lever presses as covariate) or number of minutes to first active lever press (latency). The relapse test data were also analyzed using a $\chi^{2}$ test to examine the relationship between Abstinence Day and the relapse status of rats (low vs high relapsing).

Pearson's correlations examined the relationship between alcohol seeking in Context B after $30 \mathrm{~d}$ abstinence and average home-cage consumption $(\mathrm{g} / \mathrm{kg} / 24 \mathrm{~h})$, average self-administration alcohol deliveries, active lever presses and timeout lever presses for an early time point (first 5 $\mathrm{min}$ ), late time point (first $10 \mathrm{~min}$ ), or the total for the $20 \mathrm{~min}$ operant session. These data were divided into the first seven sessions when the reinforcement schedule was FR-1 and the last six sessions when the reinforcement schedule was VI-30. Alcohol seeking was also correlated with average punishment alcohol deliveries, active lever presses and timeout lever presses for an early time point (first $5 \mathrm{~min}$ ), late time point (first 10 min) or the total for the 20 min operant session. For Experiment 2, Pearson's correlations examined the relationship between alcohol seeking and breakpoint as well as alcohol seeking and the number of alcohol deliveries, active lever presses and timeout lever presses for an early time point (first $5 \mathrm{~min}$ ), late time point (first $10 \mathrm{~min}$ ), or the total for the $2 \mathrm{~h}$ PR session.

In Experiment 3, immunohistochemical data were analyzed as cell counts $/ \mathrm{mm}^{2}$ of a given brain region as the dependent variable. To compare Fos expression between rats with a heightened propensity to relapse versus rats with a low propensity to relapse in Context $\mathrm{B}$, a median split was performed on the Day 30 Abstinence Context B relapse data (James et al., 2011). This resulted in a relapse score of 20; rats that had relapse scores $<20$ were allocated to the "Low relapsing" group and rats that had relapse scores 20 were allocated to the "High relapsing" group. One-way ANOVAs then assessed the effect of abstinence Day 30 treatment condition (Alcohol, Low relapsing, High relapsing) on the number of Fos cells $/ \mathrm{mm}^{2}$. Post hoc comparisons were assessed using least significant differences tests. Pearson's correlations examined the relationship between alcohol seeking in Context B and Fos expression.

In Experiment 4, one-way ANOVAs assessed the effect of Treatment (vehicle, $\mathrm{M}+\mathrm{B}$ ) on alcohol seeking (inactive lever presses as covariate) and latency in Context B after $30 \mathrm{~d}$ abstinence. In Experiment 5, a twoway between-subjects ANOVA assessed the effect of Drug Treatment (vehicle, $\mathrm{M}+\mathrm{B}$ ) or Context (Contexts A or B) on alcohol seeking (inac- 
tive lever presses as covariate) and latency after $1 \mathrm{~d}$ abstinence. A one-way ANOVA assessed the effect of $\mathrm{M}+\mathrm{B}$ or vehicle on distance traveled $(\mathrm{m})$ in the locomotor arena. All analyses were performed using SPSS v25 ( $\alpha$ $0.05)$. Data are presented as mean \pm SEM.

\section{Results}

Experiment 1: context-induced relapse to alcohol seeking following acute or prolonged abstinence

Rats consumed high quantities of alcohol during the home-cage period and reliably self-administered alcohol in Context A (Fig. $1 B)$. In Context $\mathrm{B}$, rats reduced alcohol self-administration with increasing shock intensity (Fig. $1 B$ ).

Alcohol seeking behavior following acute or prolonged abstinence There was a significant interaction between Test Context $\times$ Abstinence Day $\left(F_{(1,63)}=4.578, p=0.036\right.$; Fig. $\left.1 C\right)$. There was also a significant main effect of Context $\left(F_{(1,63)}=40.081, p<0.0001\right)$ with rats tested in Context $A$ having a greater number of active lever presses compared with rats tested in Context B. There was no significant main effect of Abstinence Day $\left(F_{(1,63)}=0.021, p=\right.$ 0.884). In Context $B$ there was variability in relapse data on Day 30 , therefore rats were divided using a median split (James et al., 2011), which resulted in a criterion Relapse Score of 20 active lever presses. Rats with relapse scores $<20$ formed the "Punishment low relapsing" group and rats with relapse scores $\geq 20$ formed the "Punishment high relapsing" group. Using this criterion, there was a $\sim$ threefold increase in the number of rats relapsing in Context B after $30 \mathrm{~d}$ abstinence, from $16 \%$ at Day 1 compared with $52 \%$ at Day 30 (Fig. 1C). Chi-square analyses revealed a significant relationship between Abstinence Day and the relapse status of rats in Context $\mathrm{B}\left(\chi^{2}=\right.$ $4.080, p=0.043)$. There was no significant relationship between Abstinence Day and relapse status in Context $\mathrm{A}\left(\chi^{2}=\right.$ $0.001, p=0.971)$. Analysis of latency to first lever press revealed no interaction between Test Context $\times$ Abstinence Day $\left(F_{(1,64)}=1.082, p=0.302\right)$. There was a significant main effect of Context on latency to first lever press $\left(F_{(1,64)}=26.715, p<\right.$ $0.0001)$ with rats tested in Context B having a greater latency to first lever press compared with Context A. There was no significant main effect of Abstinence Day on latency $\left(F_{(1,64)}=\right.$ $0.911, p=0.343)$. These data indicate that $30 \mathrm{~d}$ abstinence following punishment-imposed abstinence increases relapse propensity in the punishment context (Fig. 1C).

Experiment 2: predicting the propensity to relapse in Context $B$, the punishment context following prolonged abstinence Retrospective Pearson's correlations were performed between home-cage drinking, self-administration, punishment and propensity to relapse after $30 \mathrm{~d}$ abstinence. There were no significant correlations between alcohol drinking history and relapse propensity in Context B ( $p$ values $>0.05$; Table 2 ). Evidence suggests that a history of high alcohol intake does not necessarily predict future alcohol seeking behavior, rather there is a relationship between motivation for alcohol and compulsive alcohol seeking (Giuliano et al., 2015, 2018). Therefore, 14 rats were tested using a PR task (Richardson and Roberts, 1996) during self-administration to assess motivation for alcohol (Fig. 2A). There was no significant correlation between Context $\mathrm{B}$ active lever presses after prolonged abstinence and PR breakpoint, $r=0.153, p=0.602$ (Fig. $2 B$ ). Additionally, there were no significant correlations between Context $\mathrm{B}$ active lever presses after prolonged abstinence and the number of alcohol deliveries $(r=-0.034, p=0.909)$ or the number of active lever presses $r=0.063, p=0.830)$ in the first
Table 2. Correlations between alcohol drinking history and the propensity to relapse after $30 \mathrm{~d}$ abstinence in the punishment context

\begin{tabular}{|c|c|c|c|c|}
\hline $\begin{array}{l}\text { Alcohol drinking } \\
\text { history measure }\end{array}$ & $\begin{array}{l}\text { Pearson } \\
\text { correlation } \\
\text { with propensity } \\
\text { to relapse }\end{array}$ & $\begin{array}{l}\text { FR-1 schedule } \\
\text { Pearson } \\
\text { correlation } \\
\text { with propensity } \\
\text { to relapse }\end{array}$ & $\begin{array}{l}\text { VI-30 schedule } \\
\text { Pearson } \\
\text { correlation } \\
\text { with propensity } \\
\text { to relapse }\end{array}$ & $\begin{array}{l}\text { Punishment } \\
\text { Pearson } \\
\text { correlation } \\
\text { with propensity } \\
\text { to relapse }\end{array}$ \\
\hline Home-cage consumption & 0.000 & & & \\
\hline Early alcohol deliveries & & 0.236 & 0.389 & 0.361 \\
\hline Early active lever presses & & 0.201 & 0.397 & 0.309 \\
\hline Early timeout lever presses & & 0.182 & 0.275 & 0.282 \\
\hline Late alcohol deliveries & & 0.286 & 0.223 & 0.396 \\
\hline Late active lever presses & & 0.283 & 0.329 & 0.337 \\
\hline Late timeout lever presses & & 0.394 & 0.341 & 0.305 \\
\hline Total alcohol deliveries & & 0.268 & 0.294 & 0.404 \\
\hline Total active lever presses & & 0.242 & 0.374 & 0.309 \\
\hline Total timeout lever presses & & 0.226 & 0.381 & 0.303 \\
\hline
\end{tabular}

Retrospective Pearson's correlations were performed between alcohol seeking behavior in Context B after $30 \mathrm{~d}$ abstinence and average home-cage consumption ( $\mathrm{g} / \mathrm{kg} / 24 \mathrm{~h})$, average self-administration alcohol deliveries, active lever presses and timeout lever presses for an early time point (first 10mins), late time point (last $10 \mathrm{~min}$ ) or the total for the 20 min operant session. These data were divided into the first seven sessions when the reinforcement schedule was FR-1 and the last six sessions when the reinforcement schedule was VI-30. Alcohol seeking was also correlated with average punishment alcohol deliveries, active lever presses and timeout lever presses for an early time point (first $10 \mathrm{~min}$ ), late time point (last $10 \mathrm{~min}$ ) or the total for the 20 min operant session. Data presented as the Pearson correlation coefficient $(r) . n=21$

20 min of the PR task. Thus motivation for alcohol does not predict propensity for relapse in Context B in this paradigm.

Experiment 3: Fos expression associated with contextinduced relapse to alcohol seeking following prolonged abstinence

There was a significant effect of Abstinence Group (Day 30 Alcohol $n=6$, Day 30 Punishment low relapsing $n=7$, Day 30 Punishment high relapsing $n=8$ ) on the number of Fos-positive cells in the $\operatorname{LH}\left(F_{(2,18)}=4.112, p=0.034\right), \operatorname{PVT}\left(F_{(2,18)}=4.494\right.$, $p=0.026), \operatorname{LHb}\left(F_{(2,17)}=4.943, p=0.020\right)$, and AI $\left(F_{(2,17)}=\right.$ $5.682, p=0.016)$. Post hoc analyses showed significant differences between groups Day 30 Alcohol and Day 30 Punishment high relapsing in the $\mathrm{LH}, \mathrm{PVT}$, LHb, and $\mathrm{AI}$ ( $p$ values $<0.05$; Table 3 ). In the $\mathrm{AI}$ and $\mathrm{LHb}$, there was also a significant difference between groups Day 30 Punishment low relapsing and Day 30 Punishment high relapsing ( $p$ values $<0.05$; Fig. 3 ; Table 3 ). Only the AI had a significant correlation between alcohol seeking in the punishment context and Fos counts, $r=0.609, p=0.047$ (Fig. 3B; Table 4).

\section{Experiment 4: effect of AI inactivation on context-induced relapse to alcohol seeking in the punishment context following prolonged abstinence}

Experiment 4 tested a causal role of AI in context-induced relapse to alcohol seeking in Context $\mathrm{B}$, the punishment context after prolonged abstinence (Fig. $4 A$ ), using reversible inactivation with intra-AI injections of muscimol + baclofen. AI inactivation reduced context-induced relapse to alcohol seeking in the punishment context following prolonged abstinence [1/8 rats relapsed (12.5\%), compared with $5 / 9$ for vehicle $(56 \%)$; Fig. $4 \mathrm{~B}]$. There was a significant main effect of Drug $\left(F_{(1,14)}=5.700, p=0.032\right)$. Analysis of latency to first lever press revealed no significant effect of Drug $\left(F_{(1,15)}=2.542, p=0.132\right)$. These results suggest the AI plays a critical role in context-induced relapse to alcohol seeking in Context B, the punishment context after prolonged abstinence.

Experiment 5: effect of AI inactivation on context-induced relapse to alcohol seeking following $1 \mathrm{~d}$ abstinence Experiment 5 tested a causal role of AI in context-induced relapse to alcohol seeking after $1 \mathrm{~d}$ abstinence (Fig. 5), using reversible 
A

Behavioral procedure

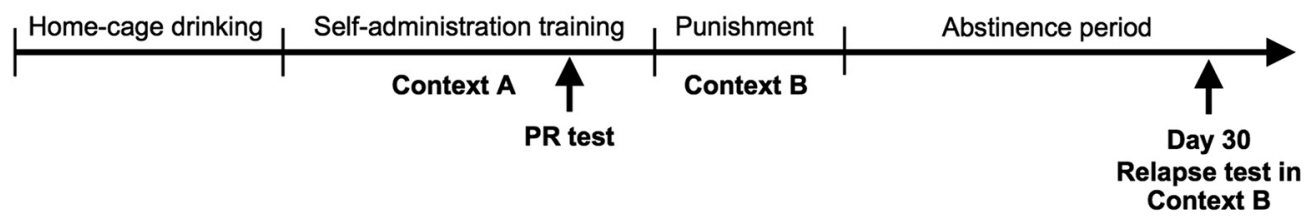

B

Alcohol seeking and progressive ratio responding

PR breakpoint

Alcohol seeking

Alcohol seeking $\times$ PR breakpoint
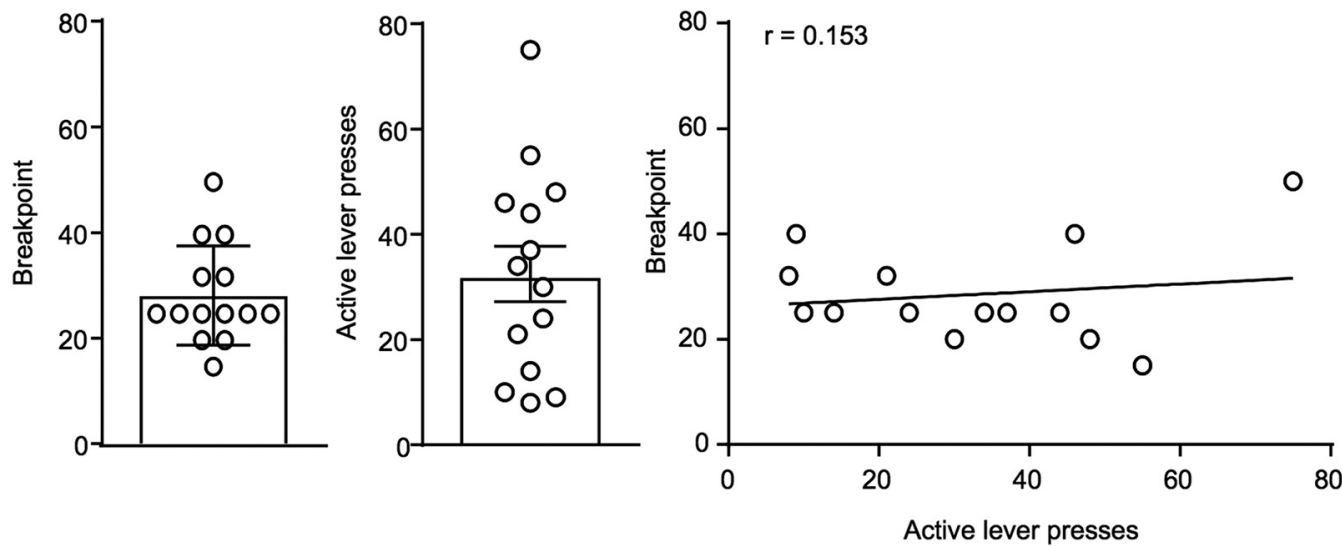

Figure 2. Predicting the propensity to relapse in Context $B$, the punishment context following prolonged abstinence. Outline of the behavioral procedure $(A)$. PR breakpoint and number of active lever presses during the relapse test in the punishment context ( $\boldsymbol{B}$, left). Correlation between PR breakpoint and alcohol seeking active lever presses in the punishment context ( $\boldsymbol{B}$, right). Data are presented as mean \pm SEM. $n=14$.

Table 3. Fos-protein expression across several brain regions following $30 \mathrm{~d}$ abstinence

\begin{tabular}{lccc}
\hline Brain region & Context A, alcohol & $\begin{array}{l}\text { Context B, } \\
\text { punishment low } \\
\text { relapsing }\end{array}$ & $\begin{array}{l}\text { Context B, } \\
\text { punishment high } \\
\text { relapsing }\end{array}$ \\
\hline Al & $32.102 \pm 10.460$ & $48.679 \pm 13.150^{\#}$ & $108.517 \pm 23.707^{* *}$ \\
Alp & $16.064 \pm 5.467$ & $24.793 \pm 5.639$ & $34.041 \pm 6.944$ \\
PrL & $32.645 \pm 7.045$ & $30.354 \pm 15.082$ & $73.565 \pm 26.275$ \\
IL & $36.773 \pm 9.896$ & $24.377 \pm 12.281$ & $61.105 \pm 17.219$ \\
LOFC & $120.322 \pm 32.167$ & $110.660 \pm 34.262$ & $148.329 \pm 33.813$ \\
EC & $44.752 \pm 10.964$ & $38.191 \pm 9.895$ & $73.703 \pm 18.003$ \\
VSub & $67.540 \pm 17.905$ & $56.231 \pm 8.594$ & $71.599 \pm 5.483$ \\
PVT & $60.854 \pm 7.797$ & $101.111 \pm 21.192$ & $131.584 \pm 15.626^{* *}$ \\
LH & $19.615 \pm 2.517$ & $27.611 \pm 4.990$ & $37.364 \pm 4.561^{*}$ \\
LHb & $12.300 \pm 3.617$ & $16.474 \pm 3.929$ & $39.292 \pm 9.577^{*}$ \\
BLA & $12.862 \pm 4.768$ & $9.913 \pm 2.630$ & $20.926 \pm 4.162$ \\
CeA & $26.909 \pm 9.721$ & $54.359 \pm 19.369$ & $38.956 \pm 9.851$ \\
MeA & $40.849 \pm 11.937$ & $37.668 \pm 9.557$ & $62.679 \pm 14.002$ \\
DDG & $12.218 \pm 2.844$ & $16.454 \pm 4.637$ & $23.966 \pm 3.917$ \\
PVN & $43.589 \pm 12.772$ & $71.525 \pm 40.149$ & $67.019 \pm 19.133$ \\
NACC & $22.970 \pm 7.921$ & $19.236 \pm 8.475$ & $29.519 \pm 11.549$ \\
NACSh & $15.894 \pm 4.935$ & $17.451 \pm 7.186$ & $38.213 \pm 11.570$ \\
\hline
\end{tabular}

Data presented as average number of Fos-positive cells per $\mathrm{mm}^{2} \pm$ SEM. $n=6-8$ /group.

${ }^{*} p<0.05$ versus Alcohol group, ${ }^{* *} p<0.01$ versus Alcohol group, $\# p<0.05$ versus Punishment high relapsing group.

inactivation with intra-AI injections of muscimol + baclofen. AI inactivation did not change alcohol seeking behavior in either context following acute abstinence (Fig. $5 B$ ). There was no significant interaction between Drug $\times$ Test Context $\left(F_{(1,17)}=\right.$ $0.010, p=0.921)$. There was a significant main effect of Context $\left(F_{(1,17)}=8.959, p=0.008\right)$ with rats tested in Context A having a greater number of active lever presses compared with rats tested in Context B. There was no significant main effect of Drug $\left(F_{(1,17)}=0.004, p=0.952\right)$. Analysis of latency to first lever press revealed no significant interaction between Drug $\times$ Test Context $\left(F_{(1,17)}=2.626, p=0.124\right)$. There was a significant main effect of Context $\left(F_{(1,17)}=10.543, p=0.005\right)$ with rats tested in Context $\mathrm{B}$ having a greater latency to first lever press compared with rats tested in Context A. There was no significant main effect of Drug $\left(F_{(1,17)}=1.589, p=0.224\right)$. There was also no significant effect of $\mathrm{AI}$ inactivation on spontaneous locomotor activity $\left(F_{(1,14)}=\right.$ 2.302, $p=0.151$; Fig. $5 D$ ). These results suggest the AI does not play a critical role in context-induced relapse to alcohol seeking after acute abstinence.

\section{Discussion}

We extended a recently developed model of context-induced relapse to alcohol seeking following punishment-imposed abstinence (Marchant et al., 2013), by examining relapse after prolonged abstinence. We found an increased propensity to relapse in Context B, the punishment context after prolonged abstinence. Neither prior alcohol use history, nor the motivational strength of alcohol, predicted relapse vulnerability after prolonged abstinence. Increased propensity to relapse in the punishment context was correlated with activation of the AI, and reversible inactivation of the AI dramatically reduced the proportion of rats relapsing in the punishment context after prolonged abstinence but not following acute abstinence. Our results demonstrate a critical role of the AI in context-induced relapse to alcohol seeking in Context B, the punishment context, following prolonged abstinence. 
A

Timeline

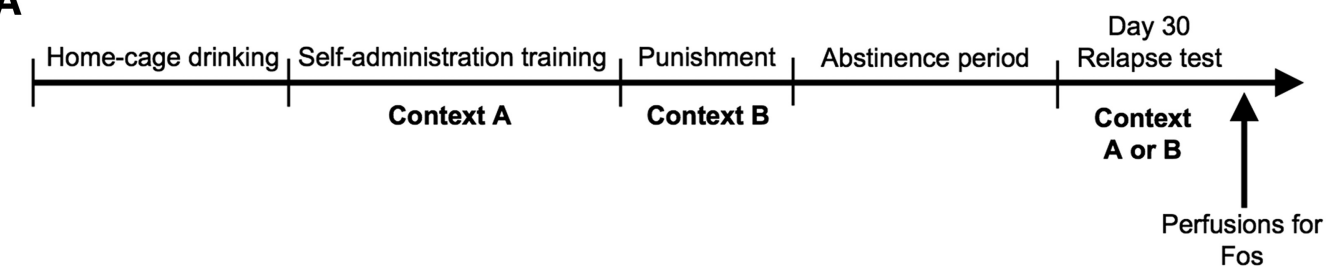

B

Anterior insular cortex Fos

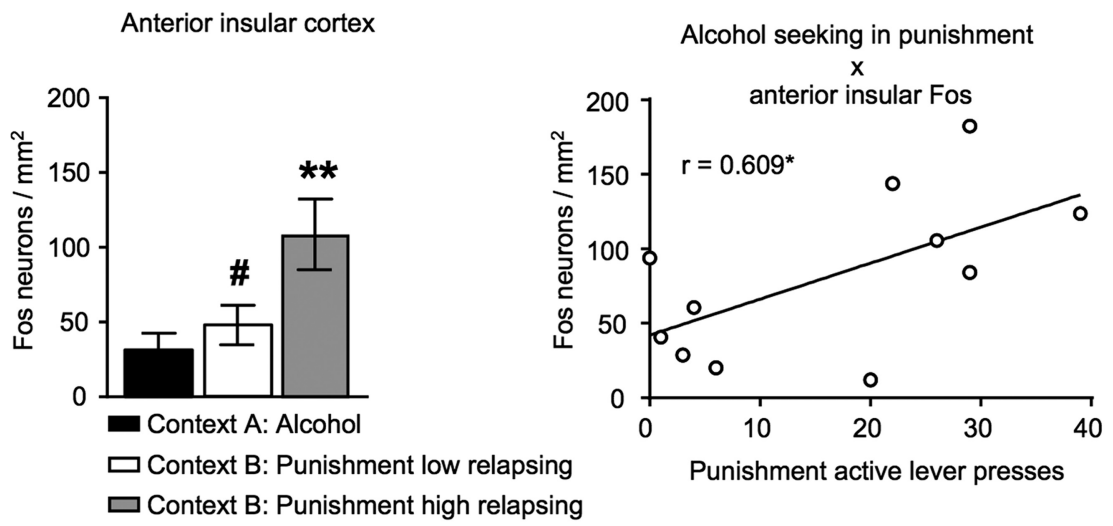

C
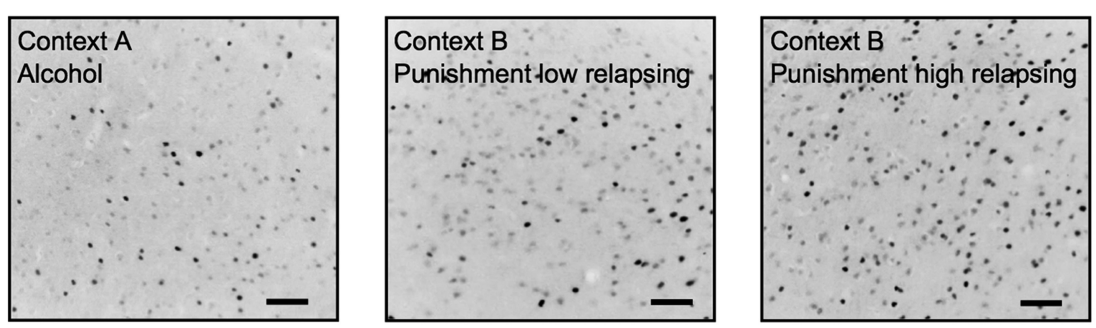

Figure 3. Context-induced relapse to alcohol seeking is associated with selective activation of the Al. Outline of the experimental procedure (A). Number of Fos-positive neurons per square millimeter in the Al in rats tested in Context A: alcohol context, or in Context B: punishment context who were either low relapsing or high relapsing. Correlation between alcohol seeking behavior in Context B: punishment context and active lever presses on relapse test $(\boldsymbol{B})$. Photomicrographs representing Fos-protein expression across each treatment group (C). Data are presented as mean \pm SEM. $n=6-8 /$ group. Scale bar, $200 \mu \mathrm{m} .{ }^{* *} p<0.01$ versus Alcohol group, $\# p<0.05$ versus Punishment high relapsing group, ${ }^{*} p<0.05$.

Table 4. Correlations between Fos expression and alcohol seeking behavior in either Context B: Punishment context, or Context A: Alcohol context following prolonged abstinence

\begin{tabular}{lcc}
\hline & \multicolumn{2}{l}{ Pearson correlation } \\
\cline { 2 - 3 } Brain region & Context B, punishment & Context A, alcohol \\
\hline Al & $0.609^{*}$ & -0.033 \\
Alp & 0.193 & -0.122 \\
PrL & 0.277 & -0.241 \\
IL & 0.393 & -0.362 \\
LOFC & 0.414 & -0.556 \\
EC & 0.190 & -0.150 \\
VSub & 0.175 & 0.480 \\
PVT & 0.193 & -0.088 \\
LH & 0.446 & -0.291 \\
LHb & 0.324 & 0.310 \\
BLA & 0.277 & -0.431 \\
CeA & -0.226 & -0.198 \\
MeA & 0.365 & -0.780 \\
DDG & 0.315 & 0.159 \\
PVN & -0.118 & 0.239 \\
NAcC & -0.031 & -0.707 \\
NACSh & 0.083 & 0.017 \\
\hline D
\end{tabular}

Data presented as the Pearson correlation coefficient $(r) \cdot n=6-8 /$ group. ${ }^{*} p<0.05$.
Individual variability in the propensity to relapse and predicting relapse vulnerability following prolonged abstinence

In humans with alcohol use disorder, relapse can occur following weeks, months, or years of abstinence, and environments previously associated with alcohol availability are often potent precipitants of relapse (Wikler, 1973; Collins and Brandon, 2002; Ferri et al., 2006). In preclinical models, drug seeking progressively increases during abstinence (Shalev et al., 2001) termed incubation of craving (Grimm et al., 2001). Time-dependent increases in cue-induced reinstatement of alcohol seeking have also been demonstrated (Bienkowski et al., 2004), as well as after punishment-imposed abstinence of methamphetamine and food seeking behavior (Krasnova et al., 2014). Interestingly, in follow-up studies this group found that the incubation effect was predominantly due to enhanced cue-induced methamphetamine seeking after withdrawal (Torres et al., 2017). We did not observe increased alcohol seeking in Context A after $30 \mathrm{~d}$ abstinence. This lack of "incubation" has also been demonstrated for contextinduced reinstatement of alcohol and methamphetamine seeking following extinction (Zironi et al., 2006; Adhikary et al., 2017). Our findings suggest that alcohol seeking in the alcoholassociated context following voluntary abstinence does not in- 
A

Timeline

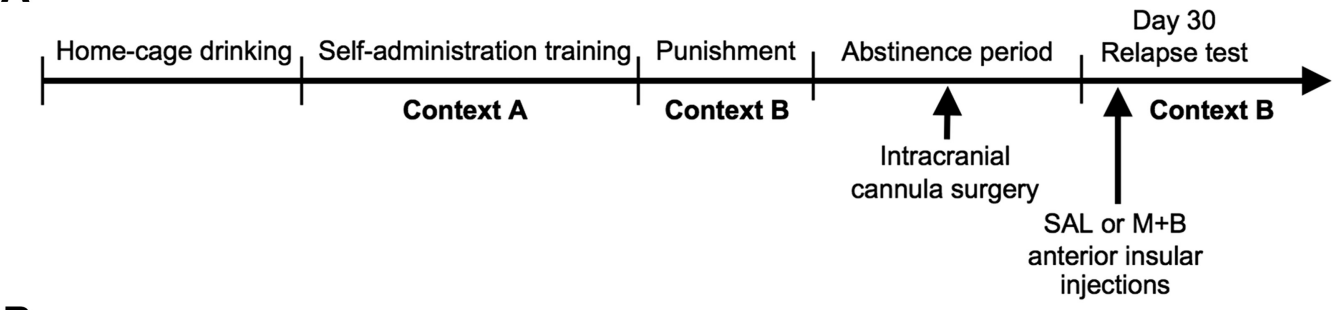

B

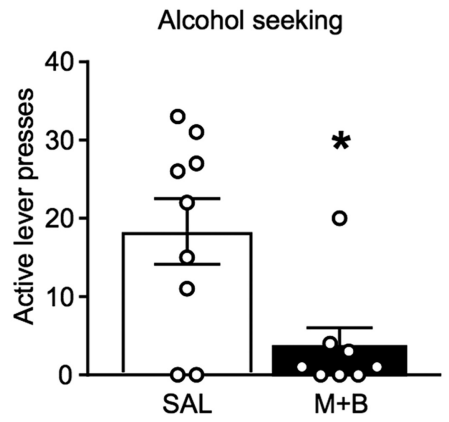

C

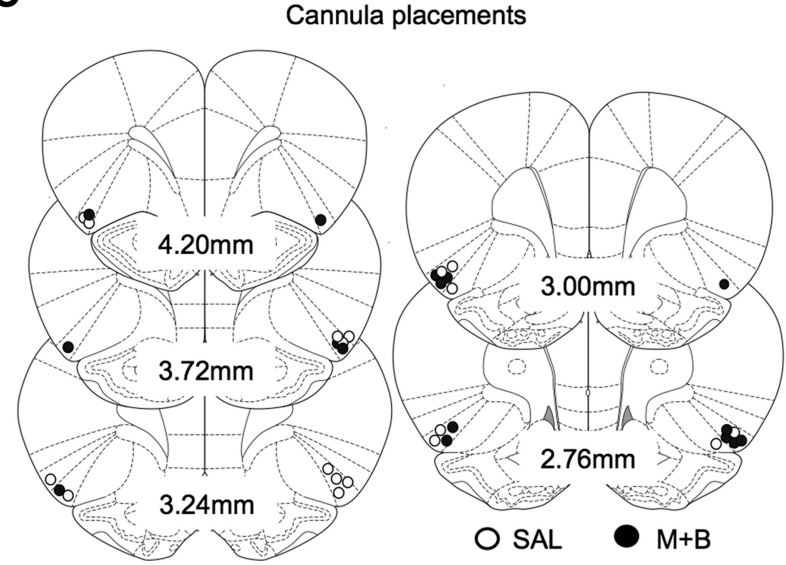

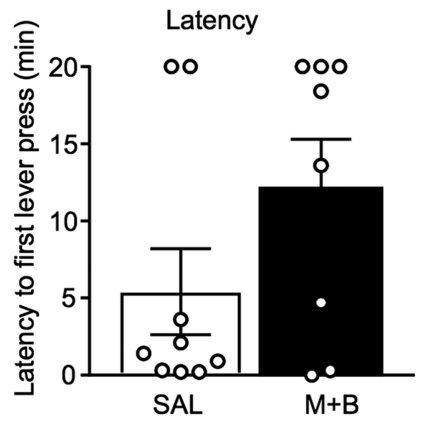

Representative cannula placement

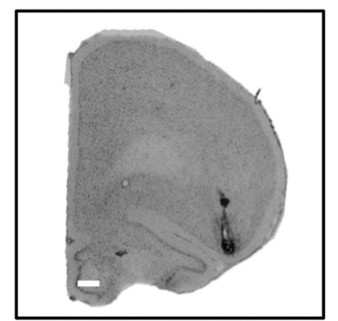

Figure 4. Anterior insular cortex inactivation prevents context-induced relapse to alcohol seeking in Context B, the punishment context following prolonged abstinence. Outline of the experimental timeline $(\boldsymbol{A})$. Number of active lever presses (left) and latency to first lever press (right) in the punishment context following prolonged abstinence $(\boldsymbol{B})$. Approximate cannula placements (mm from bregma) of the injector tips for the Al (C). SAL, saline, M+B, muscimol + baclofen. Data are presented as mean \pm SEM. $n=8-9 / g$ roup. Scale bar, $1000 \mu \mathrm{m} .{ }^{*} p<0.05$.

crease over the time span of our procedure, or if it does, the peak of relapse behavior may occur either before or sometime after $30 \mathrm{~d}$. Indeed, a potential criticism of the punishment model used is the relatively brief alcohol-free period before Day 1 relapse testing, because alcohol is still delivered and consumed during punished responding. As previously mentioned, our data do however show a clear effect of context on Day 1 relapse testing, suggesting that even after a short period of abstinence, rats can differentiate between "safe" and "dangerous" environments.

Our most striking finding is increased alcohol seeking, and increased individual variability, in the punishment context, Context B, after $30 \mathrm{~d}$ abstinence. This equates to increased alcohol seeking despite the knowledge of likely negative consequences. In contrast to the alcohol context, we repeatedly observed a clear increase in alcohol seeking in the punishment context, Context B, over time. Previous studies have shown that context-induced reinstatement of alcohol seeking following $15 \mathrm{~d}$ abstinence does not increase responding for alcohol in the extinction context (Zironi et al., 2006). Thus, our study identifies an important difference between extinctionbased and punishment-based models of abstinence and relapse.
In our procedure, the punishment context is associated with alcohol availability, but alcohol seeking is suppressed by increasing shock intensity. Thus, the neural mechanisms responsible for behavioral control in this context likely involve an interaction between those processing reward and those processing the aversive stimulus (Barberini et al., 2012; Marchant et al., 2018b). In contrast, the extinction context involves experimenter-imposed extinction where the reward is no longer delivered. Although there are distinct neural substrates responsible for this, this operational difference results in vastly different learning and neurobiological mechanisms between extinction and punishment. In our model, foot shock presumably causes increased salience of the alcohol-associated cues in the punishment context for relapse vulnerable rats. In this scenario, our data suggest time-dependent increases in alcohol seeking in response to cues with strong valence in susceptible rats. Importantly, the rats that do relapse in the punishment context had higher latency to respond compared with those tested in the alcohol context. This suggests that the extended abstinence period does not completely diminish the contextual association of punishment. 
A

Timeline

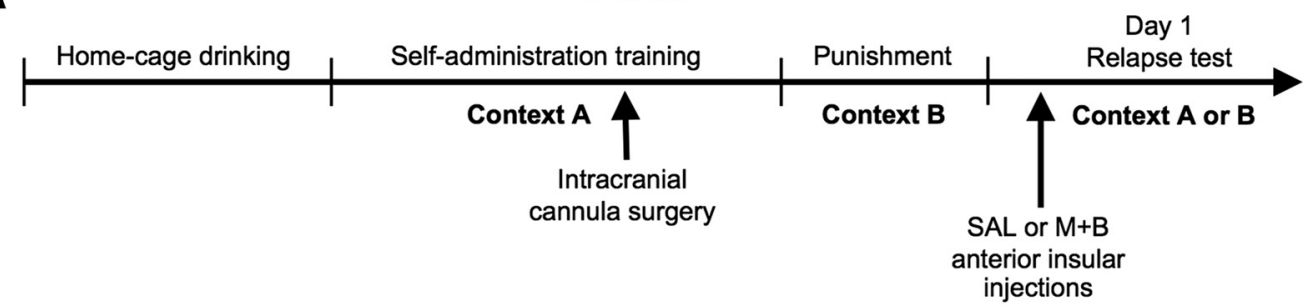

B

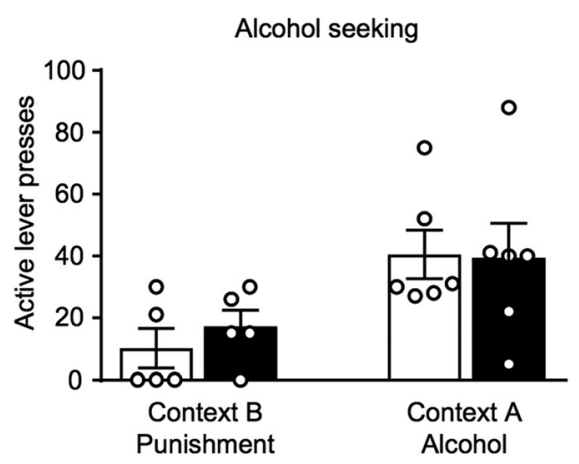

C
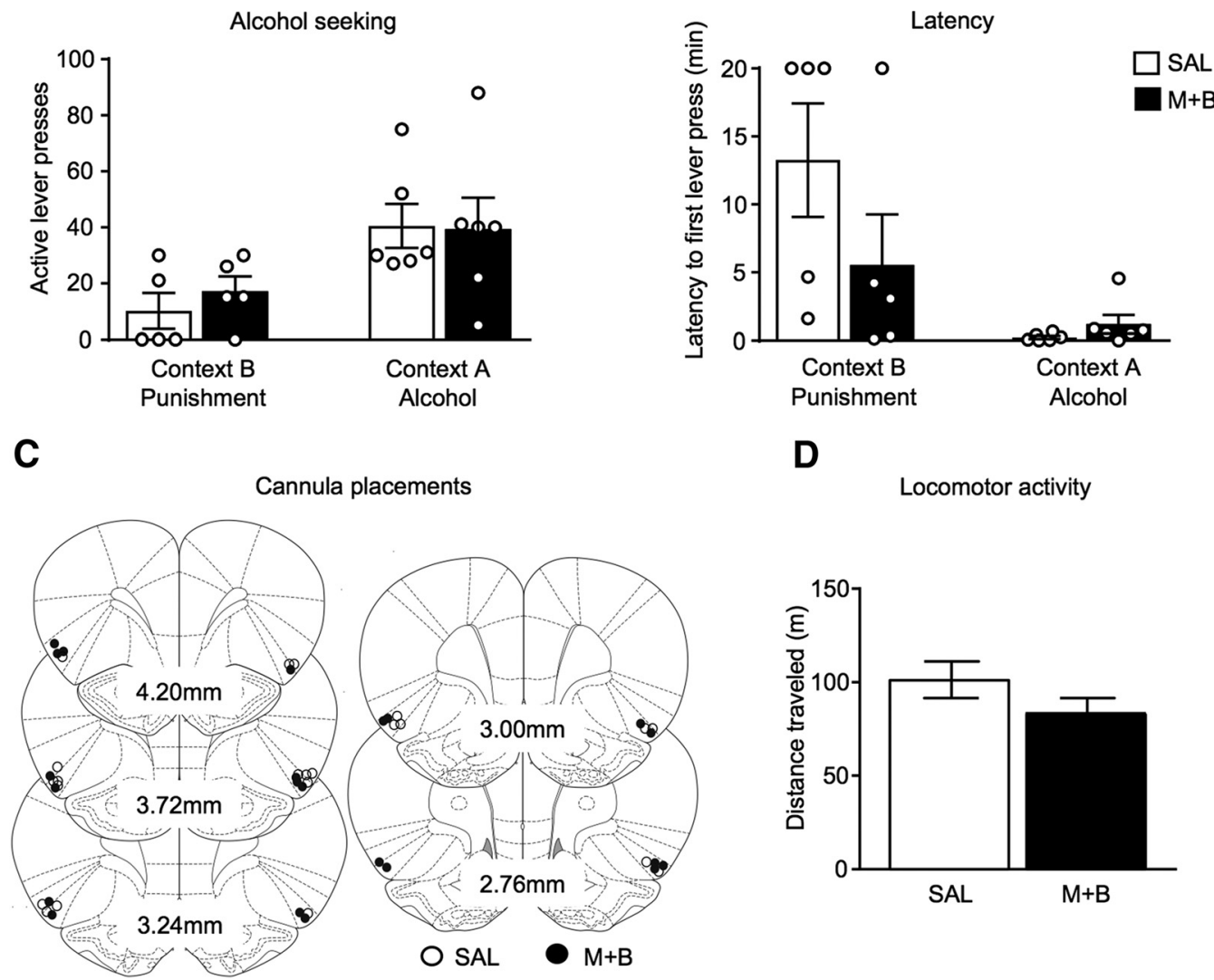

D

Locomotor activity

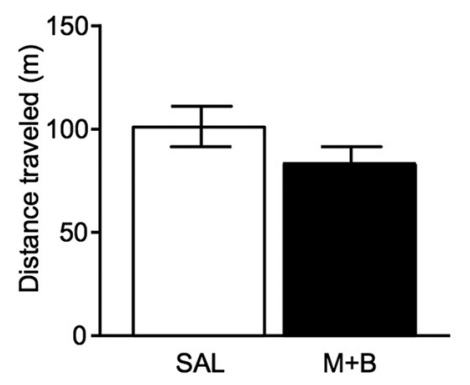

Figure 5. Anterior insular cortex inactivation has no effect on context-induced relapse to alcohol seeking in following acute abstinence. Outline of the experimental timeline $(\boldsymbol{A})$. Number of active lever presses (left) and latency to first lever press (right) following acute abstinence (B). Approximate cannula placements ( $\mathrm{mm}$ from bregma) of the injector tips for the Al (C). SAL, saline, $\mathrm{M}+\mathrm{B}$, muscimol + baclofen. There was no effect of Al inactivation on locomotor activity (D). Data are presented as mean $\pm \mathrm{SEM} n=5-6 /$ group.

We observed significant variability in the propensity to relapse in Context $\mathrm{B}$, the punishment context, after prolonged abstinence. Our attempt to predict relapse following prolonged abstinence was unsuccessful. Interestingly, these data are in line with human studies which also suggest that history of alcohol intake is not enough to predict relapse (Maisto et al., 2016; DiClemente and Crisafulli, 2017). Additionally, individual interoceptive responses to punishment might impact on alcohol relapse propensity. However, there was no correlation between relapse propensity and punishment self-administration responding in the current dataset, and we have previously shown that variability in the response to shock is not predicted by measures of alcohol selfadministration (Marchant et al., 2018a).

\section{Role of the $\mathrm{AI}$ in the propensity to relapse following} prolonged abstinence

We found a critical role for the $\mathrm{AI}$ in context-induced relapse to alcohol seeking in the punishment context following prolonged abstinence, but not acute abstinence. The AI drives motivational behavior through interoception or by modulating approach versus avoidance behavior (Paulus and Stewart, 2014). Reversible inactivation of the AI reduces cue-induced reinstatement of cocaine and nicotine seeking and context-induced reinstatement of cocaine seeking (Cosme et al., 2015; Pushparaj et al., 2015; Arguello et al., 2017). Additionally, chemogenetic inhibition of AI to nucleus accumbens core projections reduces alcohol selfadministration (Jaramillo et al., 2018a,b). Recently, Pelloux et al. (2018) showed increased Fos expression in the AI in Context A following context-induced relapse to cocaine seeking after punishment-imposed abstinence. Additionally, Venniro et al. (2017) showed that AI inactivation, and chemogenetic inhibition of AI to central amygdala projections, reduced relapse to methamphetamine seeking in Context A after voluntary abstinence achieved via a model of contingency management in Context B. To our knowledge, the current data are the first to link the AI with the propensity to relapse in the punishment context (B) after prolonged abstinence. 
In humans, altered insular cortex volume is associated with alcohol relapse and increased activation of the anterior insular has been associated with compulsive alcohol seeking despite aversive consequences in heavy drinkers (Cardenas et al., 2011; Grodin et al., 2018). Additionally, blood oxygen level-dependent fMRI signals are increased in the insular of cocaine and methamphetamine addicts when exposed to drug-associated cues (Garavan et al., 2000; Yin et al., 2012). Finally, damage to the insular cortex reduces relapse rates in cocaine addicts (Naqvi et al., 2007; Gaznick et al., 2014). These data, combined with our preclinical studies, highlight a pivotal role for the AI in relapse.

\section{Conclusions}

In conclusion, we show an increased propensity to relapse in Context B, the punishment context, following prolonged abstinence. Neither alcohol intake history nor the motivational strength of the alcohol predicted relapse. We found increased Fos expression in the AI in rats relapsing in the punishment context, which positively correlated with alcohol seeking. Reversible inactivation confirmed a critical role for the AI in the propensity to relapse in the punishment context after prolonged abstinence. Our findings provide further evidence that alcohol use history cannot be used to accurately predict relapse. Identification of reliable biomarkers that enable precision medicine may ultimately improve relapse prevention.

\section{References}

Adhikary S, Caprioli D, Venniro M, Kallenberger P, Shaham Y, Bossert JM (2017) Incubation of extinction responding and cue-induced reinstatement, but not context- or drug priming-induced reinstatement, after withdrawal from methamphetamine. Addict Biol 22:977-990. CrossRef Medline

Arguello AA, Wang R, Lyons CM, Higginbotham JA, Hodges MA, Fuchs RA (2017) Role of the agranular insular cortex in contextual control over cocaine-seeking behavior in rats. Psychopharmacology 234:2431-2441. CrossRef Medline

Barberini CL, Morrison SE, Saez A, Lau B, Salzman CD (2012) Complexity and competition in appetitive and aversive neural circuits. Front Neurosci 6:170. CrossRef Medline

Bienkowski P, Rogowski A, Korkosz A, Mierzejewski P, Radwanska K, Kaczmarek L, Bogucka-Bonikowska A, Kostowski W (2004) Timedependent changes in alcohol-seeking behaviour during abstinence. Eur Neuropsychopharmacol 14:355-360. CrossRef Medline

Blume AW, Schmaling KB, Marlatt GA (2006) Recent drinking consequences, motivation to change, and changes in alcohol consumption over a three month period. Addict Behav 31:331-338. CrossRef Medline

Bouton ME, Bolles RC (1979) Role of conditioned contextual stimuli in reinstatement of extinguished fear. J Exp Psychol Anim Behav Process 5:368-378. CrossRef Medline

Brown RM, Kim AK, Khoo SY, Kim JH, Jupp B, Lawrence AJ (2016) Orexin-1 receptor signalling in the prelimbic cortex and ventral tegmental area regulates cue-induced reinstatement of ethanol-seeking in iP rats. Addict Biol 21:603-612. CrossRef Medline

Burgos-Robles A, Kimchi EY, Izadmehr EM, Porzenheim MJ, Ramos-Guasp WA, Nieh EH, Felix-Ortiz AC, Namburi P, Leppla CA, Presbrey KN, Anandalingam KK, Pagan-Rivera PA, Anahtar M, Beyeler A, Tye KM (2017) Amygdala inputs to prefrontal cortex guide behavior amid conflicting cues of reward and punishment. Nat Neurosci 20:824-835. CrossRef Medline

Campbell EJ, Watters SM, Zouikr I, Hodgson DM, Dayas CV (2015) Recruitment of hypothalamic orexin neurons after formalin injections in adult male rats exposed to a neonatal immune challenge. Front Neurosci 9:65. CrossRef Medline

Campbell EJ, Barker DJ, Nasser HM, Kaganovsky K, Dayas CV, Marchant NJ (2017a) Cue-induced food seeking after punishment is associated with increased fos expression in the lateral hypothalamus and basolateral and medial amygdala. Behav Neurosci 131:155-167. CrossRef Medline

Campbell EJ, Mitchell CS, Adams CD, Yeoh JW, Hodgson DM, Graham BA, Dayas CV (2017b) Chemogenetic activation of the lateral hypothalamus reverses early life stress-induced deficits in motivational drive. Eur J Neurosci 46:2285-2296. CrossRef Medline

Campbell EJ, Flanagan JPM, Marchant NJ, Lawrence AJ (2018) Reduced alcohol-seeking in male offspring of sires exposed to alcohol selfadministration followed by punishment-imposed abstinence. Pharmacol Res Perspect 6:e00384. CrossRef Medline

Cardenas VA, Durazzo TC, Gazdzinski S, Mon A, Studholme C, Meyerhoff DJ (2011) Brain morphology at entry into treatment for alcohol dependence is related to relapse propensity. Biol Psychiatry 70:561-567. CrossRef Medline

Collins BN, Brandon TH (2002) Effects of extinction context and retrieval cues on alcohol cue reactivity among nonalcoholic drinkers. J Consult Clin Psychol 70:390-397. CrossRef Medline

Contreras M, Billeke P, Vicencio S, Madrid C, Perdomo G, González M, Torrealba F (2012) Role for the insular cortex in long-term memory for context-evoked drug craving in rats. Neuropsychopharmacology 37: 2101-2108. CrossRef Medline

Cosme CV, Gutman AL, LaLumiere RT (2015) The dorsal agranular insular cortex regulates the cued reinstatement of cocaine-seeking, but not foodseeking, behavior in rats. Neuropsychopharmacology 40:2425-2433. CrossRef Medline

Crombag HS, Shaham Y (2002) Renewal of drug seeking by contextual cues after prolonged extinction in rats. Behav Neurosci 116:169-173. CrossRef Medline

DiClemente CC, Crisafulli MA (2017) Alcohol relapse and change needs a broader view than counting drinks. Alcohol Clin Exp Res 41:266-269. CrossRef Medline

Dragunow M, Peterson MR, Robertson HA (1987) Presence of c-fos-like immunoreactivity in the adult rat brain. Eur J Pharmacol 135:113-114. CrossRef Medline

Farid WO, Lawrence AJ, Krstew EV, Tait RJ, Hulse GK, Dunlop SA (2012) Maternally administered sustained-release naltrexone in rats affects offspring neurochemistry and behaviour in adulthood. PLoS One 7:e52812. CrossRef Medline

Ferri M, Amato L, Davoli M (2006) Alcoholics Anonymous and other 12step programmes for alcohol dependence. Cochrane Database Syst Rev 3:CD005032. CrossRef Medline

Garavan H, Pankiewicz J, Bloom A, Cho JK, Sperry L, Ross TJ, Salmeron BJ, Risinger R, Kelley D, Stein EA (2000) Cue-induced cocaine craving: neuroanatomical specificity for drug users and drug stimuli. Am J Psychiatry 157:1789-1798. CrossRef Medline

Gaznick N, Tranel D, McNutt A, Bechara A (2014) Basal ganglia plus insula damage yields stronger disruption of smoking addiction than basal ganglia damage alone. Nicotine Tob Res 16:445-453. CrossRef Medline

Ge F, Wang N, Cui C, Li Y, Liu Y, Ma Y, Liu S, Zhang H, Sun X (2017) Glutamatergic projections from the entorhinal cortex to dorsal dentate gyrus mediate context-induced reinstatement of heroin seeking. Neuropsychopharmacology 42:1860-1870. CrossRef Medline

Giuliano C, Goodlett CR, Economidou D, García-Pardo MP, Belin D, Robbins TW, Bullmore ET, Everitt BJ (2015) The novel $\mu$-opioid receptor antagonist GSK1521498 decreases both alcohol seeking and drinking: evidence from a new preclinical model of alcohol seeking. Neuropsychopharmacology 40:2981-2992. CrossRef Medline

Giuliano C, Peña-Oliver Y, Goodlett CR, Cardinal RN, Robbins TW, Bullmore ET, Belin D, Everitt BJ (2018) Evidence for a long-lasting compulsive alcohol seeking phenotype in rats. Neuropsychopharmacology 43 : 728-738. CrossRef Medline

Gossop M, Green L, Phillips G, Bradley B (1989) Lapse, relapse and survival among opiate addicts after treatment: a prospective follow-up study. $\mathrm{Br} J$ Psychiatry 154:348-353. CrossRef Medline

Grimm JW, Hope BT, Wise RA, Shaham Y (2001) Neuroadaptation. incubation of cocaine craving after withdrawal. Nature 412:141-142. CrossRef Medline

Grodin EN, Sussman L, Sundby K, Brennan GM, Diazgranados N, Heilig M, Momenan R (2018) Neural correlates of compulsive alcohol seeking in heavy drinkers. Biol Psychiatry Cogn Neurosci Neuroimaging 3:10221031. CrossRef Medline

Hamlin AS, Newby J, McNally GP (2007) The neural correlates and role of D1 dopamine receptors in renewal of extinguished alcohol-seeking. Neuroscience 146:525-536. CrossRef Medline

James MH, Charnley JL, Flynn JR, Smith DW, Dayas CV (2011) Propensity to "relapse" following exposure to cocaine cues is associated with the 
recruitment of specific thalamic and epithalamic nuclei. Neuroscience 199:235-242. CrossRef Medline

James MH, Campbell EJ, Walker FR, Smith DW, Richardson HN, Hodgson DM, Dayas CV (2014) Exercise reverses the effects of early life stress on orexin cell reactivity in male but not female rats. Front Behav Neurosci 8:244. CrossRef Medline

Jaramillo AA, Van Voorhies K, Randall PA, Besheer J (2018a) Silencing the insular-striatal circuit decreases alcohol self-administration and increases sensitivity to alcohol. Behav Brain Res 348:74-81. CrossRef Medline

Jaramillo AA, Randall PA, Stewart S, Fortino B, Van Voorhies K, Besheer J (2018b) Functional role for cortical-striatal circuitry in modulating alcohol self-administration. Neuropharmacology 130:42-53. CrossRef Medline

Klingemann HK (1991) The motivation for change from problem alcohol and heroin use. Br J Addict 86:727-744. CrossRef Medline

Krasnova IN, Marchant NJ, Ladenheim B, McCoy MT, Panlilio LV, Bossert JM, Shaham Y, Cadet JL (2014) Incubation of methamphetamine and palatable food craving after punishment-induced abstinence. Neuropsychopharmacology 39:2008-2016. CrossRef Medline

Maisto SA, Roos CR, Hallgren KA, Moskal D, Wilson AD, Witkiewitz K (2016) Do alcohol relapse episodes during treatment predict long-term outcomes? Investigating the validity of existing definitions of alcohol use disorder relapse. Alcohol Clin Exp Res 40:2180-2189. CrossRef Medline

Marchant NJ, Khuc TN, Pickens CL, Bonci A, Shaham Y (2013) Contextinduced relapse to alcohol seeking after punishment in a rat model. Biol Psychiatry 73:256-262. CrossRef Medline

Marchant NJ, Rabei R, Kaganovsky K, Caprioli D, Bossert JM, Bonci A, Shaham Y (2014) A critical role of lateral hypothalamus in context-induced relapse to alcohol seeking after punishment-imposed abstinence. J Neurosci 34:7447-7457. CrossRef Medline

Marchant NJ, Campbell EJ, Whitaker LR, Harvey BK, Kaganovsky K, Adhikary S, Hope BT, Heins RC, Prisinzano TE, Vardy E, Bonci A, Bossert JM, Shaham Y (2016) Role of ventral subiculum in context-induced relapse to alcohol seeking after punishment-imposed abstinence. J Neurosci 36:3281-3294. CrossRef Medline

Marchant NJ, Campbell EJ, Kaganovsky K (2018a) Punishment of alcoholreinforced responding in alcohol preferring $\mathrm{P}$ rats reveals a bimodal population: implications for models of compulsive drug seeking. Prog Neuropsychopharmacol Biol Psychiatry 87:68-77. CrossRef Medline

Marchant NJ, Campbell EJ, Pelloux Y, Bossert JM, Shaham Y (2018b) Context-induced relapse after extinction versus punishment: similarities and differences. Psychopharmacology. Advance online publication. Retrieved June 1, 2018. doi: 10.1007/s00213-018-4929-1.

Naqvi NH, Rudrauf D, Damasio H, Bechara A (2007) Damage to the insula disrupts addiction to cigarette smoking. Science 315:531-534. CrossRef Medline

Nasser HM, Lafferty DS, Lesser EN, Bacharach SZ, Calu DJ (2018) Disconnection of basolateral amygdala and insular cortex disrupts conditioned approach in Pavlovian lever autoshaping. Neurobiol Learn Mem 147:3545. CrossRef Medline

O’Brien CP (1997) A range of research-based pharmacotherapies for addiction. Science 278:66-70. CrossRef Medline
Paulus MP, Stewart JL (2014) Interoception and drug addiction. Neuropharmacology 76:342-350. CrossRef Medline

Paxinos G, Watson C (2007) The rat brain in stereotaxic coordinates. Sydney, NSW: Academic.

Pelloux Y, Hoots JK, Cifani C, Adhikary S, Martin J, Minier-Toribio A, Bossert JM, Shaham Y (2018) Context-induced relapse to cocaine seeking after punishment-imposed abstinence is associated with activation of cortical and subcortical brain regions. Addict Biol 23:699-712. CrossRef Medline

Perry CJ, McNally GP (2013) A role for the ventral pallidum in contextinduced and primed reinstatement of alcohol seeking. Eur J Neurosci 38:2762-2773. CrossRef Medline

Piazza PV, Deminière J, Le Moal M, Simon H (1989) Factors that predict individual vulnerability to amphetamine self-administration. Science 245:1511-1513. CrossRef Medline

Pushparaj A, Kim AS, Musiol M, Trigo JM, Le Foll B (2015) Involvement of the rostral agranular insular cortex in nicotine self-administration in rats. Behav Brain Res 290:77-83. CrossRef Medline

Richardson NR, Roberts DC (1996) Progressive ratio schedules in drug selfadministration studies in rats: a method to evaluate reinforcing efficacy. J Neurosci Methods 66:1-11. CrossRef Medline

Shalev U, Morales M, Hope B, Yap J, Shaham Y (2001) Time-dependent changes in extinction behavior and stress-induced reinstatement of drug seeking following withdrawal from heroin in rats. Psychopharmacology 156:98-107. CrossRef Medline

Simms JA, Steensland P, Medina B, Abernathy KE, Chandler LJ, Wise R, Bartlett SE (2008) Intermittent access to $20 \%$ ethanol induces high ethanol consumption in Long-Evans and Wistar rats. Alcohol Clin Exp Res 32:1816-1823. CrossRef Medline

Torres OV, Jayanthi S, Ladenheim B, McCoy MT, Krasnova IN, Cadet JL (2017) Compulsive methamphetamine taking under punishment is associated with greater cue-induced drug seeking in rats. Behav Brain Res 326:265-271. CrossRef Medline

Venniro M, Caprioli D, Zhang M, Whitaker LR, Zhang S, Warren BL, Cifani C, Marchant NJ, Yizhar O, Bossert JM, Chiamulera C, Morales M, Shaham Y (2017) The anterior insular cortex $\rightarrow$ central amygdala glutamatergic pathway is critical to relapse after contingency management. Neuron 96:414-427.e8. CrossRef Medline

Wikler A (1973) Dynamics of drug dependence. implications of a conditioning theory for research and treatment. Arch Gen Psychiatry 28:611616. CrossRef Medline

Wise RA (1973) Voluntary ethanol intake in rats following exposure to ethanol on various schedules. Psychopharmacologia 29:203-210. CrossRef Medline

Yin JJ, Ma SH, Xu K, Wang ZX, Le HB, Huang JZ, Fang KM, Liao LM, Cai ZL (2012) Functional magnetic resonance imaging of methamphetamine craving. Clin Imaging 36:695-701. CrossRef Medline

Zironi I, Burattini C, Aicardi G, Janak PH (2006) Context is a trigger for relapse to alcohol. Behav Brain Res 167:150-155. CrossRef Medline

Zuo W, Fu R, Hopf FW, Xie G, Krnjević K, Li J, Ye JH (2017) Ethanol drives aversive conditioning through dopamine 1 receptor and glutamate receptor-mediated activation of lateral habenula neurons. Addict Biol 22:103-116. CrossRef Medline 